\title{
Feminism in the Novels of Shobha De
}

\author{
Astha Mangal \\ Research Scholar, Deptt. of English, Kumaun University, Nainital, UK
}

\begin{abstract}
:
Feminism, Self-realization, Indian Women, New Women, Indian literature in English has journeyed a long way to achieve its present glory and grandeur present a good number of women writers offering through their writings the penetrative insight into the complex issues of life. The novels of these women writers analyze the world of women, their sufferings as victims of male hegemony, they also express social, economic and political upheavals in Indian society.
\end{abstract}

Reference to this paper should be made as follows:

\section{Astha Mangal,}

Feminism in the Novels of Shobha De,

Notions 2018, Vol. IX, No.2, pp. 13-17,

Article No. 3

Online available at :

http://anubooks.com/

?page_id $=34$ 
Among the contemporary women writers Shobha de claims to be writing "Popular fiction," saying that she is "a pioneer" in this field. She also claims to be among the first to explore the world of the urban woman in India. Through her novels she has tried to shatter the patriarchal hegemony in the Indian society fed on well known injections of the Manu-smriti. The word 'Feminism' seems to refer to an intense awareness of identity as a woman and interest in feminine problems. The subjugation of woman is a central fact of history and it is the main cause of all psychological disorders in society. The agonistic definition, feminism is seen as the struggle against all forms of Struggle all forms of patriarchal and sexiest aggression, such oppositional definition projects feminism as the necessary resistance to the patriarchal power, logically then the aim of feminism as a theory of imagination becomes abolition of itself along with its opponents.

Shobha De is one of the popular feminist writers, super model, celebrity journalist, bestselling author is shining a bright in the firmament of Indian fiction. She gained popularity and recognition not only in India but across the world also. She has been endowed with extraordinary talent to delve into the depth of human heart. Her frank narration of incidents and open- heartedness occupy unchallenged position in the field of Indian literatut-e. Praising her Paul Robert writes, "A good writer, enigmatic, straightforward, crude, erudite, girlish, and wise". She has immense knowledge of Mumbai, and its stardom. Mumbai always attracts the people due to its charm and glamour, living in the various corners of the country. Shobha De is writer of the post. Colonial-period. She has painted her characters with the bright colours and with the particular motives. She has explored many burning issues in very attractive frame work. She has projected the female characters stronger than men who never consider subjugation as their destiny. Shobha De has penetrated how the moral values of the society are being shattered before the glamour and materialism. It is none but Shobha De, who is producing the third generation novelists. Writers of this third generation are female, and write about female's concerns and predicaments. Shobha de presents the psychological crisis and dilemma of woman through her female characters. She has observed, women are rendered the passive, subordinate roles throughout their lives. De's female characters are not shown as the dependents, but they are derived by ambition, lust, greed and hate. They are seen engrossed in carving new horizon for their struggle. They feel happy to see men defeated by themselves. Behind their thinking there has been hate to men. As since long times they have been objects of male subjectivity.

All rules are made to tie woman with the hard shackles favouring man. The prevailing phallocentric ideologies create a hostile atmosphere for Shobha 
De's female creations. De's female characters are the modern, educated and well awaked ladies who step forward in accordance with demand of changing society. We clearly witness the rapid change in the social, cultural and moral norms of the society. Today the whole patriarchal set up of the society is much suffocating and un-progressing to woman in which they do not desire to live willingly. They are crying to change the thinking of man towards woman. They have equal capacity, to prove that they need opportunity. If that is provided, they can do better than men. Thus they long for equality, and liberty in the society.

In all societies, a woman is culturally assigned certain norms of behaviour such as standards of conduct, taste and decorum; any deviation from or violation of the ideal image of woman hood makes her an unruly, obstinate woman fo be condemned by society. But woman forced by man to accept the status of an inferior compared to that of man, hence woman must struggle against male controlled institutions and ideologies must have solidarity among themselves, by biological instincts. Hence, in order to gain equality and to realize their human potential, women must become autonomous. The female characters of the novelist have thirst for power and wealth. As they fully know only economic independence can enable them to make their strong position in the society. They challenge men to defeat them, and love to emerge as stronger than men. In the pursuit of materialistic material and sexual gratification they go to great extent from where they never think to go back. Unlike Anita Desai, Bhavani Bhattacharya, Shashi Deshpande, Kamala Markandaya, Kiran Desai, Arundhati Roy, Nayantara Sahgal, Manju Kapoor, Githa Hariharan etc. Shobha De does not show suppression and exploitation of woman. Instead of that she depicts the erotic life, free from the spirituality, of the upper class. De's all novels depict different roles of woman and the grim reality of life. Significant thing in the lives of De's female characters is their playing with the lust, and do not feel any hitch to betray anyone to achieve their goals. Her female characters portray the feministic outlook of the novelist very skillfully.

Mikki in Sisters establishes her father's business after his death in Plaincrash. In handling her father's business she emerges as a well and prominent business woman. She is in many ways better than her husband. These woman in the foregoing chapters maltreatment of parents towards children especially girl children is slightly concentrated. Shobha De has exhibited the impact of marital discord upon the children. Girl — children do not meet self — respect and dignity in the patriarchal system of the family. Because of unhealthy surroundings they cultivate the feeling of insecurity. Her feinale characters like Mikki and Alislia (Sisters), Noor (Snapshots), Aasha Rani (Starry Nights) Nisha (Sultry Days) undergo ill-treatment 
at the hands of the patriarchal parents. Girl — children are used as the tools of earning money and livelihood in their families. Huge burden of the familial responsibilities falls on their shoulders since childhood. De's protagonists in their childhood become victims of a loveless marital life. The phallocentric fathers look down upon the girl children and dismiss them as trivial and trite.

Because of this humiliation they raise their voices against men. In their revolt against the dogmatic attitude of the society quite contradictorily they begin to resemble the male chauvinists in their attitudes towards other. Minx (Strange Obsession) and Aparna, Rashmi and Surekha (Snapshots) are turned into hard hearted women who do care little of others. It means they do not feel sorry for the others' misery caused by them. Their such rigid and cruel attitude are result of their constant detest for men. Even in the 21 st century women, have touched all arena of life but in house they are made to realize their subdued status. As they are assigned to monotonous works no matter how they are successful outside of their house. She has no freedom to enjoy her life and to act freely. None raises his fingers upon men. Everyone expects sublime reverence from wife paying less attention on the behavioural pattern of the husband.

These women are career conscious that they do not think in terms of a settled family life, at least not in the traditional form of family and marriage. They long to be woman of substance. They involve themselves in so called artistic pursuits, literary gatherings and other such activities that promise publicity, popularity, and wealth.

Shobah De, through her Novels i.e. Socialite Evening, Starry Nights, Sisters advocate the institution of marriage. Marriage confers financial and social security. Marriage cannot be sustained only on the basis of its name. Mutual understanding and compromise from both sides make it durable and everlasting. Between married couples mental and emotional relationships should be maintained. Love, care, understanding, appreciation, respect, trust and acceptance should be accommodated in the life of married couples and lack of any one of above mentioned decides the breakdown of marital relationship. When these needs are not satisfied, relationship crumbles. The married couples of De do not have tolerance and time. Karuna, Ritu, Anjali, Winni, Swati, (Socialite Evenings), Mikki, Malitiben, Leelababen, Urmi, Sapna, Sudha Ben, Rainw-ibliai's wife (Sisters), Vimal, , Bindiya, Manju, Veenaben, Karen, Janine, Pramila, Ruki, Nislia Verma, Sindhi woman (Sultry Days) Swati, Reenia, Aparna, Rashmi, Surekha, Noor, Champa Bai (Snapshots), Maya, Maya's, mother (thoughts), Manish,Indu, Ritika, Sushinita, Monisha, Simran, Sumila, Vandana, Ambika, Florence D' Souza, Anila, (small betrayals), Minx, Amrita, Sangita Singh (Strange 
Obsession), Aasha, Rani, Sudha, Rani, Suhaila, Geetha Devi, Sheth Amire Chand's Wife, Luban, Alice, Malini, Kishen Bhai's Wife, Sheth, (Starry Nights) etc are such examples of it Shobha De's characters (woman) are seem fulfilling their need without letting their partners know about the sources. They show complete spiritual loss.

The modern Indian woman novelists in English Anita Desai, Shashi Deshpande, Arundhati Roy, Manju Kapor, Meena Alexander, Geeta Hariharan, Kamala Markandaya made their, indelible signature in the field of English fiction. In their works they have advocated the freedom of woman from the age- long control of male domination.

According to the feminist theory, sex does not mean sexuality or sexual preference which stands for a person's pattern of erotic attraction. Lesbianism is a psychological perversion, an obsession and something like eccentricity. It should not be a part of feminism. Feminism as such has to attempt a new definition of woman's role in the wider social frame. In the name of woman's liberty Minx and Minx- like cannot be justified. Shobha De's does not approve Minx's behavior and her whimsical actions. The novelist makes her notion clear to the reader through Minx's mother, "My daughter is the severely disturbed child of a disturbed mother. She suffers from delusions, she tells lies, she makes up stories, and the number of schools she has been expelled from has their own tales to tell. Thus the option of lesbian described in Strange Obsession is not affirmed by the novelist herself. On one hand she admits the significance of lesbian, on other hands extremely, and unnatural inclination to that shows abnormality of mind. This is reflected in the character of Minx.

By presenting the various issues and changed image of women Shobha De has placed her advocacy of feminism on the record. Female's rights should not be snatched, and full right of selection. Of the good options in their life should be treated the same as man. She should not be left shedding tears on her condition. Maintainbalance between style and opinion the novelist has presented her outstanding personality before her readers and fans.

\section{References}

De Shobha, Sultry Days penguin India.

Kamali, Gender Discrimination and Feminist Awareness as Depited Contemparary Tamil writers. Journal Gender and Progress 2003 